\title{
Ovarian Cancer pT2a TNM Finding v6
}

National Cancer Institute

\section{Source}

National Cancer Institute. Ovarian Cancer pT2a TNM Finding v6. NCI Thesaurus. Code C60909.

Ovarian cancer involving one or both ovaries with extension or implants on uterus and/or fallopian tubes and without malignant cells in ascites or peritoneal washings. (from AJCC 6th Ed.) 